\title{
ANALISIS IMPLEMENTASI PSAK 101 PADA LAPORAN KEUANGAN DI KSPPS BMT AL-BINA TASIKMALAYA
}

\author{
Naurah Nazhifah ${ }^{1}$, Iwan Wisandani ${ }^{2 *}$, Lina Marlina ${ }^{3}$ \\ ${ }^{1}$ Program Studi Ekonomi Syariah, Universitas Siliwangi, nazhifahnaurah96@gmail.com \\ ${ }^{2}$ Program Studi Ekonomi Syariah, Universitas Siliwangi, Iwan Wisandani, iwanwisandani@ unsil.ac.id \\ ${ }^{3}$ Program Studi Ekonomi Syariah, Universitas Siliwangi, linamarlina@unsil.ac.id
}

\begin{abstract}
This research, to study the implementation of PSAK 101 on the presentation and preparation of financial statements in KSPPS BMT Al-Bina Tasikmalaya. That is because at the BMT Al-Bina's financial statements found a non-conformity with PSAK 101 on the presentation of sharia financial statements. PSAK 101 is a statement of financial accounting standards that regulates the basic presentation of financial statement for sharia entities. This statement regulates the requirements for the presentation, structure and minimum requirements of the contents of financial statements. The method that used in this study is a qualitative descriptive method. Data collection technique in this research uses interviews, observation, and documentation to analyze data from the practice that carried out directly at the research site. The results of the study show that BMT Al-Bina in presenting they financial statements has not fully applied PSAK No.101, because (1) does not present a statement of cash flow, (2) does not present statement of sources and distribution of zakat (3) does not present statement of source and the use of virtue funds (4) does not present notes to financial statements (5) does not provide financial reporting and financial reporting information as required by PSAK No.101.
\end{abstract}

Keyword: Financial Statements, PSAK 101, BMT

*Penulis korenpondensi, email: iwanwisandani@unsil.ac.id 


\begin{abstract}
ABSTRAK
Penelitian ini dimaksudkan untuk mengetahui implementasi PSAK 101 pada penyajian dan penyusunan laporan keuangan yang ada di KSPPS BMT Al-Bina Tasikmalaya. Hal ini dikarenakan pada laporan keuangan BMT Al-Bina ditemukan adanya ketidaksesuaian dengan PSAK 101 tentang penyajian laporan keuangan syariah. PSAK 101 adalah pernyataan standar akuntansi keuangan yang mengatur dasar penyajian catatan laporan keuangan untuk entitas syariah. Pernyataan ini mengatur pesyaratan penyajian, struktur dan pesyaratan minimal isi laporan keuangan. Adapun metode yang digunakan dalam penelitian ini adalah dengan metode deskriptif kualitatif. Teknik pengumpulan data menggunakan wawancara, observasi, dan dokumentasi. Untuk menganalisis data menggunakan analisis interaksi yang terjadi secara langsung di tempat penelitian. Dari hasil penelitian diketahui bahwa BMT Al-Bina dalam menyajikan laporan keuangannya belum sepenuhnya menerapkan PSAK No.101, dikarenakan (1) tidak menyajikan laporan arus kas, (2) tidak menyajikan laporan sumber dan penyaluran dana zakat (3) tidak menyajikan laporan sumber dan penggunaan dana kebajikan (4) tidak menyajikan catatan atas laporan keuangan (5) tidak menyajikan informasi penyusunan laporan keuangan dan kebijakan akuntansi yang disyaratkan pada PSAK No.101.
\end{abstract}

Kata Kunci: PSAK 101, Laporan Keuangan, BMT 


\section{PENDAHULUAN}

Akuntansi syariah pada dasarnya termasuk dalam bentuk penerapan dari nilai-nilai Islam sebagai agama yang tidak hanya mengatur masalah keimanan namun juga mengatur masalah kehidupan sehari-hari. Akuntansi dalam Islam merupakan alat untuk menjalankan perintah Allah SWT untuk melakukan pencatatan terkait dengan transaksi yang dilakukan suatu badan usaha (Nurhayati, 2014:80). Sesuai dengan firman Allah yang terdapat dalam QS 2:282:

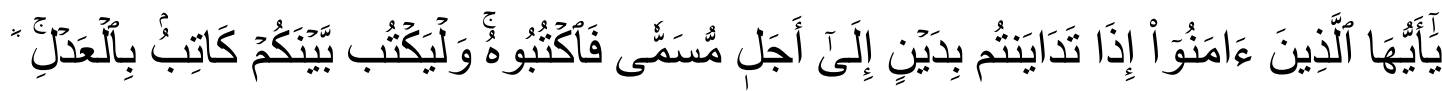

Artinya: "Hai orang-orang yang beriman, apabila kamu bermuamalah tidak secara tunai untuk waktu yang ditentukan, hendaklah kamu menuliskannya. Dan hendaklah seorang penulis di antara kamu menuliskannya dengan benar."

Baitul Mal wat Tamwil merupakan salah satu lembaga keuangan yang bergerak dalam ruang lingkup mikro. BMT mempunyai dua istilah, yaitu baitul mal dan baitul tamwil. Baitul mal lebih mengarah pada usaha-usaha pengumpulan dan penyaluran dana yang non-profit, seperti zakat, infak, dan sedekah. Adapun baitul tamwil sebagai usaha pengumpulan dan penyaluran dana komersial. Usaha-usaha tersebut menjadi bagian yang tidak terpisahkan dari BMT sebagai lembaga pendukung kegiatan ekonomi masyarakat kecil dengan berlandaskan syariat Islam (Mardani, 2017:316).

Pada BMT, laporan keuangan dibuat dengan tujuan memberikan informasi tentang posisi keuangan, kinerja dan arus kas BMT yang bermanfaat bagi manajemen dalam rangka membuat perencanaan, pengukuran kinerja, dan sebagai acuan pengambilan keputusan strategis. Laporan keuangan juga disampaikan dalam Rapat Anggota Tahunan (RAT) sebagai pertanggungjawaban manajemen atas penggunaan dana terhadap para anggota.

Dalam rangka mengatur laporan keuangan BMT maka dikeluarkan Keputusan Menteri Negara Koperasi Dan Usaha Kecil dan Menengah Republik Indonesia Nomor: 91/Kep/M.KUKM/IX/2004 tentang pentunjuk pelaksanaan Kegiatan Usaha Koperasi Jasa Keuangan Syariah, menegaskan bahwa perlakuan akuntansi yang menyangkut pengakuan, pengukuran, dan pengungkapan seluruh perkiraan dilakukan berdasarkan prinsip akuntansi syariah yang berlaku umum, yaitu mengikuti pedoman standar akuntansi keuangan syariah (Kemenkop, 2004:24). Karena BMT merupakan salah satu koperasi dengan basis syariah, maka dalam penyajian laporan keuangannya menggunakan prinsip-prinsip akuntansi syariah, yang berpedoman pada Pernyataan Standar Akuntansi Keuangan Syariah Nomor 101 tentang penyajian laporan keuangan syariah.

PSAK 101 mengatur penyajian secara wajar posisi keuangan, kinerja dan arus kas entitas syariah, sehingga tujuan laporan keuangan tersebut dapat tercapai. Penyajian laporan keuangan yang diatur dalam PSAK 101 terdiri dari komponen-komponen laporan keuangan yang lengkap, meliputi; (1) Neraca; (2) Laporan Laba Rugi; (3) Laporan Arus Kas; (4) Laporan Perubahan Ekuitas; (5) Laporan Sumber dan Penggunaan Dana Zakat; (6) Laporan 
Sumber Penggunaan Dana Kebajikan dan (7) Catatan atas Laporan Keuangan (DSAK-SAK Syariah, 2017:3).

Seperti yang telah diuraikan sebelumnya bahwa Koperasi Syariah dalam menyajikan laporan keuangannya berpedoman pada PSAK 101. Oleh karena itu BMT Al-Bina juga perlu menerapkan PSAK 101 pada penyajian laporan keuangannya. Namun pada praktiknya penulis mendapatkan beberapa permasalahan terkait dengan penyajian laporan keuangan yang ada di BMT Al-Bina.

Meskipun pengurus sudah menerima pelatihan terkait akuntansi syariah, namun pada penyusunan laporan keuangan masih terlihat mengacu pada PSAK 27 Tahun 2009. Pada laporan Keuangan BMT Al-Bina juga hanya terdapat Laporan Neraca, Laporan Laba Rugi, dan Laporan Perubahan Ekuitas, sedangkan untuk Laporan Arus Kas BMT sering kali tidak disusun, serta BMT Al-Bina juga tidak menyusun Laporan Sumber dan Penggunaan Dana Zakat dan Laporan Sumber dan Penggunaan Dana Kebajikan yang merupakan komponen yang ada di PSAK 101. Selain itu, pada neraca keuangan BMT Al-Bina juga ditemukan, penggabungan antara pos Dana Syirkah Temporer dengan pos Kewajiban yang seharusnya pada PSAK 101 dipisahkan (DSAK-PSAK 101, 2017:4).

Berangkat dari permasalahan-permasalahan yang ada di lapangan serta melihat dari urgensi atau pentingnya penyajian laporan keuangan yang efektif bagi suatu entitas syariah, serta sesuai dengan ketentuan Pernyataan Standar Akuntansi Keuangan Nomor 101, maka penulis tertarik untuk menganalisis lebih jauh mengenai Implementasi PSAK 101 pada Penyajian Laporan Keuangan di KSPPS BMT Al-Bina, Cipedes, Tasikmalaya.

\section{LITERATUR REVIEW}

\section{Penyusunan Laporan Keuangan Syariah}

Laporan keuangan menunjukan kinerja dari manajemen atau pertanggung jawaban manajemen atas sumber daya yang dipercayakan kepadanya. Dalam rangka mencapai tujuan tersebut laporan keungan menyajikan informasi mengenai entitas syariah yang meliputi; (DSAK-PSAK No. 101, 2017:4)
1) Aset
2) Liabilitas
3) Dana syirkah kontemporer
4) Ekuitas
5) Pendapatan dan beban termasuk keuntungan dan kerugian
6) Kontribusi dari dan distribusi kepada pemilik dalam kapasitasnya sebagai pemilik
7) Arus kas
8) Dana zakat
9) Dana kebajikan 
Informasi tersebut, beserta informasi lainnya dapat dilihat dalam catatan atas laporan keuangan, ini dapat membatu pengguna laporan keuangan dalam memprediksi arus kas masa depan lainnya khususnya dalam hal waktu dan kepastian diperoleh kas dan setara kas.

\section{Bentuk dan Unsur Laporan Keuangan}

Laporan keuangan entitas syariah terdiri atas (Nurhayati, 2014:99):

Posisi Keuangan Entitas Syariah

Posisi keuangan suatu entitas syariah disajikan sebagai neraca. Laporan ini berguna untuk memprediksi kemampuan perusahaan di masa yang akan datang. Pada neraca ada beberapa informasi yang disajikan yaitu;(DSAK-SAK Syariah, 2017:13)

a) Aset adalah sumber daya yang dikuasai oleh entitas syariah yang mungkin terjadi di masa depan, yang diperoleh atau dikendalikan oleh ekuitas sebagai hasil dari transaksi atau peristiwa di masa lalu.

b) Kewajiban atau Liabilitas adalah pengorbanan atas sumber daya yang mungkin terjadi di masa depan yang timbul dari kewajiban entitas syariah pada saat ini, untuk menyerahkan aset atau memberikan jasa kepada entitas lainnya dimasa depan sebagai hasil transaksi atau peristiwa di masa lalu.

c) Dana Syirkah Kontemporer adalah dana yang didapat sebagai investasi dengan jangka waktu tertentu dari individu dan pihak lainnya dimana entitas syariah dapat mengelola dana tersebut dengan bagi hasil tertentu yang telah disepakati. Dana ini tidak dapat digolongkan sebagai kewajiban, karena entitas syariah tidak memiliki kewajiban untuk mengembalikan dana saat mengalami kerugian kecuali akibat kelalaian entitas syariah tersebut. Namun dana ini juga tidak dapat digolongkan sebagai ekuitas karena mempunyai jangka waktu dan tidak memiliki hak kepemilikan yang sama seperti pemegang saham.

d) Ekuitas adalah kepemilikan atau hak residu dalam aset entitas syariah yang masih tersisa setelah dikurangi dengan kewajiban dan dana syirkah kontemporer. Ekuitas dapat disubkualifikasikan menjadi menjadi setoran modal pemegang saham, saldo laba, penyisihan saldo laba dan penyisihan penyesuaian pemeliharaan modal.

\section{PSAK No 101 Tentang Penyajian Laporan Keuangan Syariah Standar Akuntansi Keuangan (SAK) dan SAK Syariah}

Dalam usaha untuk mendorong tersusunnya norma-norma keuangan syariah yang seragam dan pengembangan produk yang selaras antara aspek syariah dan kehati-hatian pada tahun laporan dilakukan pembahasan bersama pihak yang terkait dalam Komite Akuntansi Indonesia dan pihak lainnya.

Komite ini bersama dengan Dewan Standar Akuntansi Keuangan Ikatan Akuntan Indonesia pada tahun 2007 telah mengeluarkan pernyataan standar akuntansi keuangan untuk 
transaksi kegiatan usaha dengan menggunakan akuntansi yang berlandaskan kaidah syariah (Muslim, 2015:61).

Standar akuntansi keuangan (SAK) yaitu pernyataan dan pandangan yang dikeluarkan oleh Dewan Standar Akuntansi Keuangan Ikatan Akuntan Indonesia dan Dewan Standar Akuntansi Syariah Ikatan Akuntan Indonesia serta peraturan regulator pasar modal untuk entitas yang berada di bawah pengawasannya (DSAK-PSAK No. 101, 2017:2).

SAK Syariah di keluarkan oleh Dewan Standar Akuntansi Keuangan Ikatan Akuntan Indonesia. SAK Syariah hanya digunakan oleh entitas yang melaksanakan transaksi berlandaskan atas prinsip-prinsip syariah yang dinyatakan dalam anggaran dasarnya. Dalam SAK ini mengatur pesyaratan pengakuan, pengukuran dan penghapusan transaksi dan peristiwa lain yang menggunakan prinsip-prinsip syariah.

Berikut ini adalah daftar standar akuntansi syariah yang dikeluarkan oleh Dewan Standar Akuntansi Keuangan IAI yang diberlakukan untuk entitas syariah (Muslim, 2015:61):

1. PSAK No. 59 tentang Perbankan Syariah

2. PSAK 101 tentang Penyajian Laporan Keuangan Syariah

3. PSAK 102 tentang Akuntansi Murabahah

4. PSAK 103 tentang Akuntansi Salam

5. PSAK 104 tentang Akuntansi Istishna

6. PSAK 105 tentang Akuntansi Mudharabah

7. PSAK 106 tentang Akuntansi Musyarakah

8. PSAK 107 Akuntansi Ijarah

9. PSAK 108 Akuntansi Asuransi Syariah

10. PSAK 109 Akuntansi Zakat dan Infak/Sedekah

11. PSAK 110 Akuntansi Sukuk

12. PSAK 111 Akuntansi Wa'ad

13. PSAK 112 Akuntansi Wakaf

\section{Pernyataan Standar Akuntansi Keuangan No 101}

Pedoman Standar Akuntansi Keuangan (PSAK) No 101 adalah Pernyataan yang menetapkan dasar penyajian laporan keuangan untuk entitas syariah yang selanjutnya disebut "laporan keuangan". Pernyataan ini bertujuan agar dapat dibandingkan, baik laporan keuangan sebelumnya maupun dengan laporan keuangan entitas syariah lain. Pernyataan ini mengatur pesyaratan penyajian laporan keuangan, struktur laporan keuangan, dan penyusunan laporan keuangan (DSAK-PSAK No. 101, 2017:1).

Dengan didasarkan pada studi teoritik yang sudah dilakukan maka kerangka pemikiran dalam penelitian ini dapat digambarkan dengan paradigma penelitian sebagai berikut: 


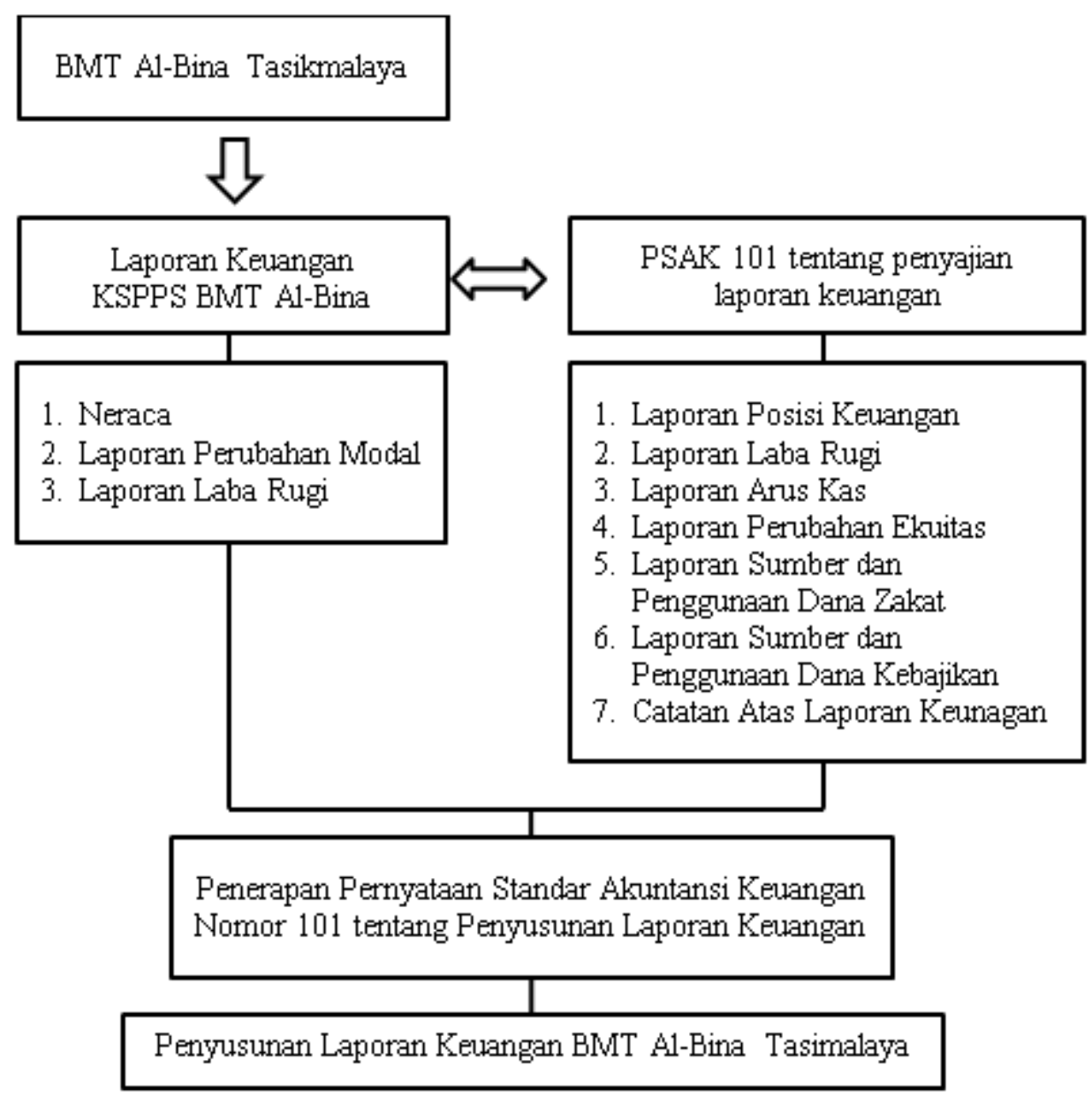

Gambar 1. Kerangka Pemikiran Penelitian

\section{Penelitian Terdahulu}

Berikut disampaikan bebrapa penelitian terdahulu :

1. Sulistyandari, meneliti tentang Perbandingan Laporan Keuangan Koperasi Syariah BMT Al-Ittihad Pekanbaru dengan PSAK 101 (Sulistyandari, 2018:6). Hasil penelitian tersebut adalah pada laporan keuangan BMT Al-Ittihad belum sepenuhnya menerapkan PSAK No.101, karena ada beberapa laporan yang tidak dibuat oleh BMT Al-Ittihad. Terdapat persamaan antara penelitian yang dilakukan oleh Sulistyandari dengan penelitian yang penulis lakukan, yaitu sama-sama meneliti tentang penerapan PSAK No.101. Sedangkan, perbedaannya terletak pada tempat penelitian.

2. Amrul Ikhsan dan Musfiari Haridhi, meneliti tentang Penerapan SAK Syariah pada Koperasi Jasa Keuangan Syariah Studi pada Baitul Qiradh di Kota Banda Aceh (Ikhsan, 2018:9). Hasil dari penelitian tersebut adalah BQ banda aceh belum dapat menyusun dan menyajikan laporan keuangan syariah sesuai dengan PSAK 101 tentang laporan keuangan syariah secara menyuluruh dan pengakuan, pengukuran, penyajian serta pengungkapan 
transaksi murabahah juga belum sesuai dengan PSAK 102 tentang akuntansi murabahah belum dilaksanakan. Penyebabnya belum diterapkannya karena kemampuan SDM BQ masih terbatas dan belum mampu menyesuaikan diri dengan peraturan yang berlaku. Persamaan penelitian yang dilakukan oleh Amrul Ikhsan dan Musfiari Haridhi dengan penelitian yang dilakukan penulis yaitu, sama-sama meneliti tentang PSAK 101 mengenai penyajian laporan keuangan syariah. Perbedaannya, Amrul Ikhsan dan Musfiari Haridhi melakukan penelitian pada penerapan seluruh Penyataan Standar Akuntansi Syariah, sedangkan penulis hanya menganalisi penerapan PSAK 101 tentang laporan keuangan saja. Amrul Ihsan dan Musfiari juga melakukan penelitian pada tujuh BQ di kota Banda Aceh, sedangkan penulis melakukan penelitian hanya di BMT Al-Bina kota Tasikmalaya.

\section{METODE}

Penelitian ini menggunakan metode penelitian kualitatif dengan pendekatan deskriptif. Data yang diambil berupa data primer, dalam hal ini melakukan wawancara kepada Bagian Keuangan BMT Al-Bina dan Manajer BMT Al-Bina. Kemudian data yang telah diperoleh diuji kebsahannya melalui teknik triangulasi yaitu: Triangulasi Sumber dimana mengecek kepada berbagai sumber, Triangulasi Teknik dimana mengecek data kepada sumber yang sama dengan teknik yang berbeda. Dalam penelitian ini, penulis mengecek data yang diperoleh dari observasi, lalu dicek dengan wawancara dan studi literatur. Sehingga penulis berharap data yang diterima valid dan benar.

\section{HASIL DAN PEMBAHASAN}

\section{Penyajian Data Laporan Keuangan KSPPS BMT Al-Bina Tasikmalaya}

Pada laporan keuangan di BMT Al Bina dibuat dengan periode bulanan dan tahunan. Proses akuntansinya hampir sama dengan siklus akuntansi di atas, pertama dari mengidentifikasi transaksi apa yang akan dilakukan, setelah itu mengukur besaran transaksi yang akan dilakukan, kemudian masuk kedalam tahap pendokumentasian transaksi berupa slip transaksi atau kwintasi, lalu transaksi yang telah didokumentasikan diringkas hingga dicatat dan diklasifikasi ke dalam buku besar. Proses ini dilakukan harian selama periode berjalan. Setelah mencapai akhir periode bulanan atau tahunan, maka akan dilanjutkan proses pengoutputan hingga menghasilkan sebuah laporan keuangan.

Laporan keuangan yang dibuat suatu entitas syariah yang sesuai dengan PSAK No. 101 pada umumnya terdiri dari tujuh komponen, yaitu; (1) laporan posisi keuangan (Neraca), (2) laporan laba rugi; (3) laporan arus kas; (4) laporan perubahan ekuitas; (5) laporan sumber dan penggunaan dana zakat; (6) laporan sumber dan penggunaan dana kebajikan serta (7) catatan atas laporan keuangan (DSAK-IAI, 2017:3).

Namun dalam praktiknya, pada laporan keuangan di KSPPS BMT Al-Bina hanya memiliki tiga komponen laporan keuangan, diantaranya; laporan posisi keuangan (neraca), laporan laba rugi dan laporan perubahan ekuitas. Hal ini dikarenakan pihak BMT hanya 
membuat komponen yang sekiranya diperlukan oleh pihak internal lembaga maupun pihak eksternal lembaga.

Berikut adalah bentuk laporan keuangan yang telah disusun oleh BMT Al-Bina per 31 Desember 2018:

Tabel 1. Neraca Per 31 Desember 2018 KSPPS BMT Al-Bina

\begin{tabular}{|c|c|c|}
\hline PERKIRAAN & \multicolumn{2}{|c|}{ JUMLAH } \\
\hline AKTIVA & & \\
\hline$\overline{\text { HARTA }}$ & & \\
\hline Kas & $\mathrm{Rp}$ & 11.243 .500 \\
\hline Simpanan Bank & $\mathrm{Rp}$ & 49.046.721 \\
\hline Simpanan Puskopsyah & $\mathrm{Rp}$ & 12.700 .000 \\
\hline Simpanan Cash Cholateral Puskopsyah & $\mathrm{Rp}$ & 63.500 .000 \\
\hline Simpanan Wajib dan Pokok Inkopsyah & $\mathrm{Rp}$ & 9.800 .000 \\
\hline Simpanan Inkopsyah & $\mathrm{Rp}$ & . \\
\hline Piutang Murabahah & $\mathrm{Rp}$ & 370.417 .850 \\
\hline Pembiayaan Mudharabah & $\mathrm{Rp}$ & 8.426 .750 \\
\hline Pembiayaan Qardhul Hasan & $\mathrm{Rp}$ & 30.841 .800 \\
\hline Perlengkapan Kantor & $\mathrm{Rp}$ & 17.301 .500 \\
\hline Biaya Dibayar Dimuka & $\mathrm{Rp}$ & 51.461 .750 \\
\hline Inventaris Kantor & $\mathrm{Rp}$ & 646.000 \\
\hline Biaya Pra Operasional & $\mathrm{Rp}$ & - \\
\hline Jumlah Aktiva & $\mathbf{R p}$ & 625.385 .871 \\
\hline PASIVA & & \\
\hline$\overline{\text { Kewajiban }}$ & & \\
\hline Simpanan Dhomanah & $\mathrm{Rp}$ & 158.571 .429 \\
\hline Simpanan Idul Fitri & $\mathrm{Rp}$ & 7.008 .671 \\
\hline Simpanan Idul Qurban & $\mathrm{Rp}$ & 177.963 \\
\hline Simpanan Berjangka & $\mathrm{Rp}$ & 30.270 .00 \\
\hline Kewajiban Zakat dan Infaq & $\mathrm{Rp}$ & 368.693 \\
\hline Cadangan Pendidikan & $\mathrm{Rp}$ & 403.000 \\
\hline Dana Ta'awun & $\mathrm{Rp}$ & 1.245 .591 \\
\hline Hutang BH Dana P3KUM & $\mathrm{Rp}$ & 17.968.384 \\
\hline Hutang Dana P3KUM & $\mathrm{Rp}$ & 62.608 .480 \\
\hline Hutang Inkopsyah & $\mathrm{Rp}$ & (217) \\
\hline Hutang Bank Syariah Mandiri & $\mathrm{Rp}$ & 19.663 .483 \\
\hline Hutang Puskopsyah & $\mathrm{Rp}$ & 142.418 .691 \\
\hline Jumlah Kewajiban & $\mathbf{R p}$ & 440.704.168 \\
\hline Modal & & \\
\hline Simpanan Pokok Khusus & $\mathrm{Rp}$ & 33.433 .000 \\
\hline Simpanan Pokok & $\mathrm{Rp}$ & 3.740 .000 \\
\hline Simpanan Wajib & $\mathrm{Rp}$ & 53.152 .862 \\
\hline
\end{tabular}




\begin{tabular}{|l|lr|}
\hline Simpanan Penyertaan Anggota & $\mathrm{Rp}$ & 3.871 .147 \\
Hibah Donasi & $\mathrm{Rp}$ & 71.390 .519 \\
Cadangan Resiko & $\mathrm{Rp}$ & 1.407 .555 \\
Cadangan Modal & $\mathrm{Rp}$ & 17.507 .500 \\
Cadangan THR dan Bonus & $\mathrm{Rp}$ & 109.126 \\
SHU & $\mathrm{Rp}$ & 69.994 \\
Pendapatan Bulan Ini & $\mathrm{Rp}$ & - \\
Jumlah Modal & $\mathbf{R p}$ & $\mathbf{1 8 4 . 6 8 1 . 7 0 3}$ \\
Jumlah Pasiva & $\mathbf{R p}$ & $\mathbf{6 2 5 . 3 8 5 . 8 7 1}$ \\
\hline
\end{tabular}

Sumber: Laporan Keuangan BMT Al-Bina Per-31 Desember 2018

Tabel 2. Laporan Laba Rugi Per 31 Desember 2018 KSPPS BMT Al-Bina

\begin{tabular}{|l|l|r|}
\hline \multicolumn{1}{|c|}{ PERKIRAAN } & \multicolumn{1}{|c|}{ JUMLAH } \\
\hline Pendapatan & & 100.612 .550 \\
Pendapatan Murabahah & $\mathrm{Rp}$ & 2.194 .000 \\
Pendapatan Dana P3KUM & $\mathrm{Rp}$ & 6.303 .000 \\
Pendapatan Administrasi & $\mathrm{Rp}$ & $\mathbf{1 0 9 . 9 0 4 . 3 0 0}$ \\
Jumlah & $\mathbf{R p}$ & \\
Beban-Beban & & \\
Beban BH Simpanan Dhomanah & $\mathrm{Rp}$ & 4.285 .392 \\
Beban BH Simpanan Idul Fitri & $\mathrm{Rp}$ & 249.240 \\
Beban BH Simpanan Idul Qurban & $\mathrm{Rp}$ & - \\
Beban BH P3KUM & $\mathrm{Rp}$ & 702.080 \\
Beban BH Penyertaan & $\mathrm{Rp}$ & 230.000 \\
Beban Zakat dan Pendidikan & $\mathrm{Rp}$ & 90.000 \\
Beban Resiko & $\mathrm{Rp}$ & 140.000 \\
Beban Transport & $\mathrm{Rp}$ & 22.145 .000 \\
Beban Listrik, Air, Tlp & $\mathrm{Rp}$ & 4.279 .854 \\
Beban Sewa Gedung & $\mathrm{Rp}$ & 9.500 .000 \\
Beban ATK Perlengkapan Kantor & $\mathrm{Rp}$ & 4.084 .200 \\
Beban Penyusutan Perlengkapan Kantor & $\mathrm{Rp}$ & 643.000 \\
Beban Gaji dan Bonus & $\mathrm{Rp}$ & 54.565 .56 \\
Beban Cadangan Modal & $\mathrm{Rp}$ & 150.000 \\
Beban BH Simpanan Wajib dan Pokok & $\mathrm{Rp}$ & 300.000 \\
Beban Operasional Lainnya & $\mathrm{Rp}$ & 3.725 .224 \\
Minus Pendapatan Bulan Ini & $\mathrm{Rp}$ & - \\
Beban BH. Deposito & $\mathrm{Rp}$ & 3.405 .000 \\
Jumlah Beban & $\mathrm{Rp}$ & $\mathbf{1 0 8 . 4 9 4 . 5 5 7}$ \\
SHU Tahun Berjalan & $\mathbf{R p}$ & \\
\hline
\end{tabular}

Sumber: Laporan Keuangan BMT Al-Bina Per-31 Desember 2018 
Tabel 3. Laporan Perubahan Modal BMT Al-Bina per 31 Desember 2018

\begin{tabular}{|c|c|c|}
\hline Modal Awal Bulan lalu & $\mathbf{R p}$ & 19.641.577 \\
\hline \multicolumn{3}{|l|}{ Penambahan } \\
\hline$\overline{\text { Simpanan Pokok Khusus }}$ & $\mathrm{Rp}$ & - \\
\hline Simpanan Pokok & $\mathrm{Rp}$ & - \\
\hline Simpanan Wajib Anggota & $\mathrm{Rp}$ & 290.000 \\
\hline Simpanan Penyertaan & $\mathrm{Rp}$ & - \\
\hline Cadangan Resiko & $\mathrm{Rp}$ & - \\
\hline Cadangan Modal & $\mathrm{Rp}$ & - \\
\hline Cadangan THR dan Bonus & $\mathrm{Rp}$ & 104.639 \\
\hline Hibah dan Donasi & $\mathrm{Rp}$ & - \\
\hline SHU Bulan Ini & $\mathrm{Rp}$ & 69.757 \\
\hline Penyesuaian & $\mathrm{Rp}$ & - \\
\hline Jumlah Penambahan & $\mathbf{R p}$ & 464.396 \\
\hline \multicolumn{3}{|l|}{ Pengurangan } \\
\hline$\overline{\text { Simpanan Pokok Khusus }}$ & $\mathrm{Rp}$ & - \\
\hline Simpanan Pokok & $\mathrm{Rp}$ & - \\
\hline Simpanan Wajib Anggota & $\mathrm{Rp}$ & - \\
\hline Simpanan Penyertaan Anggota & $\mathrm{Rp}$ & - \\
\hline Cadangan Resiko & $\mathrm{Rp}$ & 9.924 .270 \\
\hline Cadangan Modal & $\mathrm{Rp}$ & - \\
\hline Cadangan THR dan Bonus & $\mathrm{Rp}$ & 55.000 \\
\hline Cadangan Pendidikan & $\mathrm{Rp}$ & - \\
\hline Beban Gaji Dimuka & $\mathrm{Rp}$ & - \\
\hline Penyesuaian & $\mathrm{Rp}$ & - \\
\hline SHU & $\mathrm{Rp}$ & 445.000 \\
\hline Jumlah Pengurangan & $\mathbf{R p}$ & 10.424.270 \\
\hline Total Modal Bulan Ini & $\mathbf{R p}$ & 184.681 .703 \\
\hline
\end{tabular}

Sumber: Laporan Keuangan BMT Al-Bina Per-31 Desember 2018

\section{Analisis Data Laporan Keuangan di KSPPS BMT Al-Bina Tasikmalaya}

\section{Analisis Data Laporan Posisi Keuangan (Neraca) BMT Al-Bina}

Laporan posisi keuangan BMT Al-bina terdiri dari aktiva dan pasiva, dimana harta tergolong kedalam aktiva, sedangkan kewajiban dan modal tergolong ke dalam pasiva. Penggolongan ini sesuai dengan ketentuan pernyataan standar akuntansi syariah nomor 101 . Dalam PSAK No. 101, laporan posisi keuangan dibagi menjadi aktiva dan pasiva. Aktiva terdiri dari aset dan Pasiva terdiri dari liabilitas, dana syirkah kontemporer, dan ekuitas.

Dari tabel 2 dan 3 bisa dilihat perbedaan yang jelas antara neraca BMT Al-Bina dengan laporan posisi keuangan PSAK No.101. Terdapat ketidaksesuaian mulai dari penggolongan dan pengklasifikasian pos-pos serta penamaan akun yang ada pada neraca BMT Al-Bina. Berikut adalah format neraca atau laporan posisi keuangan BMT Al-Bina yang telah penulis sesuaikan dengan ketentuan PSAK No. 101. 
Tabel 4. Format Neraca BMT Al-Bina setelah Disesuaikan dengan PSAK 101

\begin{tabular}{|c|c|}
\hline Aktiva & Pasiva \\
\hline Aktiva Lancar & $\underline{\text { Liabilitas }}$ \\
\hline 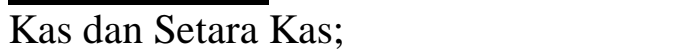 & $\overline{\text { Simpanan Dhomanah }}$ \\
\hline Kas & Simpanan Idul Fitri \\
\hline Simpanan Bank & Simpanan Idul Qurban \\
\hline Simpanan Puskopsyah & Bagi hasil yang belum dibagikan \\
\hline Simpanan Cash Cholateral Puskopsyah & Dana Ta'awun \\
\hline Simpanan Wajib dan Pokok Inkopsyah & Utang: \\
\hline Simpanan Inkopsyah & Utang Dama P3KUM \\
\hline Piutang: & Utang Inkopsyah \\
\hline Piutang Murabahah & Utang Bank Mandiri Syariah \\
\hline Pembiayaan: & Utang Puskopsyah \\
\hline Pembiayaan Mudharabah & Jumlah Liabilitas \\
\hline Biaya Dibayar Dimuka & \\
\hline Biaya Pra Operasional & $\frac{\text { Dana Syirkah Temporer }}{\text { Simpanan Berjangka }}$ \\
\hline Aktiva Tetap & Jumlah Dana Syirkah Temporer \\
\hline Inventaris Kantor & \\
\hline Perlengkapan Kantor & Ekuitas \\
\hline & $\overline{\text { Simpanan Pokok Khusus }}$ \\
\hline & Simpanan Pokok \\
\hline & Simpanan Wajib \\
\hline & Simpanan Penyertaan Anggota \\
\hline & Dana Hibah \\
\hline & Cadangan; \\
\hline & Cadangan Pendidikan \\
\hline & Cadangan Resiko \\
\hline & Cadangan Modal \\
\hline & Cadangan THR dan Bonus \\
\hline & SHU \\
\hline & Pendapatan Bulan Ini \\
\hline & Jumlah Ekuitas \\
\hline Jumlah Aktiva & Jumlah Pasiva \\
\hline
\end{tabular}

\section{Analisis Data Laporan Laba Rugi dan Penghasilan Komprehensif BMT Al-Bina}

Dalam laporan laba rugi suatu entitas syariah menyajikan pos penghasilan dan beban yang diakui pada suatu periode di dalam laporan keuangan yang menunjukan komponen laba rugi dan komponen penghasilan komprehensif lain (DSAK-PSAK No. 101, 2017:15). Pada laporan Laba Rugi BMT Al-Bina terdiri dari pendapatan dan beban yang telah diakui dalam satu periode, itu artinya penyajian laporan laba rugi di BMT Al-Bina secara umum telah sesuai dengan PSAK No. 101. 


\section{Analisis Data Laporan Arus Kas BMT Al-Bina}

Laporan arus kas bank syariah disajikan sesuai dengan PSAK No.2 tentang laporan arus kas dan PSAK No. 31 tentang akuntansi perbankan, dengan catatan menyesuaikan kegiatan dan transaksi bank syariah (Slamet, 2013:115). Pada PSAK No.101 tidak dijelaskan secara detail mengenai penyajian laporan arus kas namun laporan arus kas ini menjadi salah satu komponen penting yang harus ada pada laporan keuangan di entitas syariah.

Dalam praktiknya BMT Al-Bina tidak menyajikan laporan arus kas pada laporan keuangannya. Hal ini dikarenakan BMT Al-Bina hanya menyusun tiga komponen yang dianggap penting dan dibutuhkan oleh internal maupun eksternal, yaitu neraca, laporan laba rugi dan laporan perubahan ekuitas. Padahal informasi mengenai kas dapat menjadi salah satu indikator penting suatu perusahaan.

\section{Analisis Data Laporan Perubahan Ekuitas BMT Al-Bina}

Laporan perubahan ekuitas menyajikan perubahan yang terjadi di akun-akun ekuitas. Pada PSAK 101 entitas syariah harus menyajikan laporan perubahan ekuitas sebagai komponen utama laporan keuangan yang menunjukan: (Slamet, 2013:117)

a. Laba atau rugi bersih periode bersangkutan

b. Setiap pos pendapatan dan beban, keuntungan atau kerugian beserta jumlahnya yang berdasarkan pernyataan standar akutansi keuangan terkait diakui secara langsung dalam ekuitas

c. Pengaruh kumulatif dari perubahan kebijakan akuntansi dan perbaikan terhadap kesalahan mendasar sebagaimana diatur dalam pernyataan standar akuntansi keuangan terkait

d. Transaksi modal dengan pemilik dan distribusi kepada pemilik

e. Saldo akumulasi laba atau rugi pada awal dan akhir periode serta perubahannya

f. Rekonsiliasi antar nilai tercatat dari masing-masing jenis modal saham, agio dan cadangan pada awal dan akhir periode yang mengungkapkan secara terpisah setiap perubahan.

Sedangkan pada laporan perubahan modal di BMT Al-Bina terdiri dari modal awal periode lalu, penambahan, pengurangan modal, dan total modal akhir yang terjadi dalam satu periode.

\section{Analisis Data Laporan Sumber dan Penyaluran Zakat BMT Al-Bina}

Dalam menyajikan laporan keuanganya BMT AL-Bina tidak menyusun laporan sumber dan penggunaan dana zakat secara terpisah. Pelaporan sumber dan penggunaan dana zakat di BMT Al-Bina terdapat dalam neraca. Hal ini dikarena pada praktiknya sumber dana zakat di BMT Al-Bina masih sedikit.

Sumber zakat tersebut hanya berasal dari lembaga dan para pengurus BMT, hanya sedikit para anggota BMT yang menghimpun dana zakatnya di BMT Al-Bina. Sehingga 
manajemen merasa penyusunan laporan sumber dan penggunaan dana zakat di BMT Al-Bina belum diperlukan.

Pernyataan Standar Akuntansi Syariah No. 101 menyatakan bahwa dalam penyusunan laporan keuangan suatu entitas syariah diperlukan laporan sumber dan penggunaan dana zakat. Maka dari itu BMT Al-Bina seharusnya menyusun laporan sumber dan pengunaan dana zakat.

Berikut ini ilustrasi dari format laporan sumber dan penggunaan dana zakat di BMT Al-Bina yang sesuai dengan ketentuan PSAK 101;

Tabel.5. Format Laporan Sumber dan Penggunaan Dana Zakat di BMT Al-Bina sesuai dengan PSAK No. 101

\begin{tabular}{|l|c|}
\hline \multicolumn{1}{|c|}{ PERKIRAAN } & JUMLAH \\
\hline Sumber Dana Zakat & $\mathrm{xxx}$ \\
Zakat dari Internal BMT & $\mathrm{xxx}$ \\
Zakat dari eksternal BMT & $x x x$ \\
Jumlah & $\mathbf{( x x x )}$ \\
Penyaluran dana zakat kepada entitas pengelola zakat & $\mathbf{x x x}$ \\
Kenaikan & $\mathbf{x x x}$ \\
Saldo Awal & $\mathbf{x x x}$ \\
Saldo Akhir & \\
\hline
\end{tabular}

\section{Analisis Data Laporan Sumber dan Penggunaan Dana Kebajikan BMT Al-Bina}

Dalam menyajikan laporan keuangannya BMT AL-Bina tidak menyusun laporan sumber dan pengunaan dana kebajikan secara terpisah. Pelaporan sumber dan penggunaan dana kebajikan di BMT Al-Bina terdapat dalam neraca. Hal ini dikarenakan sumber dana kebajikan di BMT Al-Bina masih berasal dari modal BMT serta penyaluran dana kebajikan di BMT Al-Bina diperuntukan hanya untuk pengurus khususnya dan anggota.

Ada beberapa sumber dana kebajikan untuk suatu entitas syariah, diantaranya; dari modal sendiri, keuntungan atau laba entitas syariah tersebut, individu atau lembaga yang mempercayakan infaknya pada entitas syariah tersebut, dana infak dan sedekah, dan pendapatan yang diragukan. Di BMT Al-Bina sendiri sumber dana kebajikan rata-rata berasal dari modal dan masih sedikit dari infak atau sedekah anggota. Sehingga manajemen merasa 
penyusunan laporan sumber dan penggunaan dana kebajikan di BMT Al-Bina belum diperlukan.

Pernyataan Standar Akuntansi Syariah No. 101 menyatakan bahwa dalam penyusunan laporan keuangan suatu entitas syariah diperlukan laporan sumber dan penggunaan dana kebajikan. Selain untuk mengukur seperti apa penghimpunan dan penyaluran dananya, hal ini juga merupakan suatu bentuk pertanggung jawaban manajemen BMT. Maka dari itu pentingnya BMT Al-Bina dalam menyusun laporan sumber dan penggunaan dana kebajikan.

Berikut ini ilustrasi dari format laporan sumber dan penggunaan dana kebajikan di BMT Al-Bina yang sesuai dengan ketentuan PSAK 101;

Tabel 7. Format Laporan Sumber dan Penggunaan Dana Kebajikan BMT Al-Bina Sesuai dengan PSAK No.101

\begin{tabular}{|l|r|}
\hline \multicolumn{1}{|c|}{ PERKIRAAN } & JUMLAH \\
\hline Sumber Dana Kebajikan & \\
\hline Infak dari BMT & $\mathbf{x x}$ \\
Sedekah & $\mathbf{x x x}$ \\
Hasil pengelolaan wakaf & $\mathbf{x x x}$ \\
Pengembalian dana kebajikan produktif & $\mathbf{x x x}$ \\
Denda & $\mathbf{x x x}$ \\
Pendapatan nonhalal* & $x x x$ \\
Jumlah & \\
Penggunaan Dana Kebijakan & $(\mathbf{x x x})$ \\
Dana kebajikan produktif & $(\mathbf{x x x})$ \\
Sumbangan & $(\mathbf{x x x})$ \\
Penggunaan lainnya untuk kepentingan umum & $(x x x)$ \\
Jumlah & $\mathbf{x x x}$ \\
KENAIKAN & $\mathbf{x x x}$ \\
SALDO AWAL & $\mathbf{x x x}$ \\
SALDO AKHIR & \\
*pendapatan nonhalal merupakan pendapatan yang tidak halal bagi & \\
entitas pelapor namun halal bagi pihak yang menerima & \\
penganaannya dalam dana kebajikan & \\
\hline
\end{tabular}

\section{SIMPULAN}

Bedasarkan dari pembahasan dan data-data yang telah dianalisis serta diuraikan di atas. Maka penulis menarik kesimpulan bahwa, penyajian laporan keuangan di BMT Al-Bina 
belum sepenuhnya menerapkan PSAK No. 101. Hal ini dikerenakan BMT Al-Bina dalam pertanggungjawabkan laporan keuangannya hanya menyajikan Neraca, Laporan Laba Rugi dan Laporan Perubahan Ekuitas. BMT Al-Bina tidak menyajikan laporan arus kas, laporan sumber dan pengunaan dana zakat secara terpisah (disajikan pada neraca), tidak menyajikan laporan sumber dan penggunaan dana kebajikan secara terpisah (menyajikannya pada neraca) dan BMT Al-Bina juga tidak menyajikan catatan atas laporan keuangan.

Dalam menyusun laporan keuangannya BMT Al-Bina masih berpedoman pada PSAK No. 27 tahun 2009 tentang akuntansi perkoperasian. Yang menjadi perbedaan PSAK 101 dengan PSAK 27 adalah pada pos dana syirkah temporer yang dalam PSAK 27 masih tergolong kedalam kewajiban atau liabilitas. Berdasarkan PSAK No 101 dinyatakan bahwa dalam neraca terdiri dari aktiva = kewajiban + dana syirkah temporer + ekuitas. Sedangkan di dalam neraca BMT Al-Bina dana syirkah temporer masih digolongkan kedalam kewajiban karena berpacu pada PSAK 27.

Laporan keuangan BMT Al-Bina belum sesuai dengan PSAK No. 101 karena disebabkan oleh faktor internal dan ekstenal. Faktor internal yang menyebabkan BMT AlBina belum sesuai dengan PSAK No. 101 yaitu karena pihak BMT belum memahami secara mendalam tentang PSAK 101 dan pihak manajemen sudah merasa bahwa laporan keuangan yang selama ini dibuat sudah memenuhi kebutuhan BMT. Sedangkan faktor eksternalnya adalah kurangnya pengawasan dari pihak-pihak yang berkepentingan terhadap laporan keuangan BMT Al-Bina.

\section{REFERENSI}

Amrul Ikhsan dan Musfiari Haridhi, Penerapan Standar Akuntansi Keuangan Syariah pada Koperasi Jasa Keuangan Syariah (Studi pada Baitul Qiradh di Kota Banda Aceh), Jurnal Ilmiah Mahasiswa Ekonomi Akuntansi, Vol. 2 No. 3.

Ikatan Akuntan Indonesia. 2016. Standar Akuntansi Keuangan Syariah. Jakarta: IAI

Mardani. 2015. Aspek Hukum Lembaga Keuangan Syariah di Indonesia. Jakarta: Prenandamedia Group

Muslim, Sarip. 2015. Akuntansi Keuangan Syariah. Bandung: CV Pustaka Setia

Nurhayati, Sri dan Wasilah. 2014. Akuntansi Syariah di Indonesia. Jakarta: Salemba Empat.

Republik Indonesia, Peraturan Menteri Negara Koperasi Dan Usaha Kecil Menengah Republik Indonesia Nomor:91/Kep/M.KUKM/IX/2004 tentang Petunjuk Pelaksanaan Kegiatan Usaha Koperasi Keuangan Syariah. 
Sulistyandari. 2018. Analisis Perbandingan Laporan Keuangan Koperasi Syariah BMT AlIttihad Pekan Baru dengan PSAK 101. Menara Ekonomi ISSN, Vol. 4, No.1., 125-139

Wiyono, Slamet dan Taufan Maulamin. 2012. Memahami Akuntansi Syariah di Indonesia. Jakarta: Mitra Wacana Media. 